\title{
The Alpstein in three dimensions: fold-and-thrust belt visualization in the Helvetic zone, eastern Switzerland
}

\author{
Journal Article \\ Author(s): \\ Sala, Paola; Pfiffner, O. Adrian; Frehner, Marcel (D) \\ Publication date: \\ 2014-12 \\ Permanent link: \\ https://doi.org/10.3929/ethz-b-000093390
}

Rights / license:

In Copyright - Non-Commercial Use Permitted

Originally published in:

Swiss Journal of Geosciences 107(2-3), https://doi.org/10.1007/s00015-014-0168-6 


\title{
The Alpstein in three dimensions: fold-and-thrust belt visualization in the Helvetic zone, eastern Switzerland
}

\author{
Paola Sala $\cdot$ O. Adrian Pfiffner • Marcel Frehner
}

Received: 14 August 2013/Accepted: 9 September 2014/Published online: 11 December 2014

(C) Swiss Geological Society 2014

\begin{abstract}
To investigate the geometrical relationships between folding and thrust faulting, we built a 3D geological model of the Helvetic fold-and-thrust belt in eastern Switzerland from several existing and two newly drawn cross-sections in the Säntis area. We partly redrew existing cross-sections and validated them by checking for line length balance; to fill areas with no data we drew additional cross-sections. The model was built based on surface interpolation of the formation interfaces and thrusts between the cross-sections, which allowed generating eight main surfaces. In addition, we used cave data to validate the final model in depth. The main structural elements in the Säntis area, the Säntis Thrust and the Sax-Schwende Fault, are also implemented in the model. The result is a 3D structural model of the area, which provides an intuitive way for examining a portion of a complex structural nappe. The 3D model highlights the shapes of the main anticlinesyncline pairs and how these fold trains vary laterally in amplitude and wavelength. It shows how lateral variations in fold style correlate with regional shortening gradients as
\end{abstract}

Editorial handling: A. G. Milnes.

Electronic supplementary material The online version of this article (doi:10.1007/s00015-014-0168-6) contains supplementary material, which is available to authorized users.

P. Sala $(\bowtie) \cdot$ O. A. Pfiffner

Institute of Geological Sciences, University of Bern,

Baltzerstrasse 1+3, 3012 Bern, Switzerland

e-mail: sala@geo.unibe.ch

P. Sala

Eni E\&P, Via Emilia 1, 20097 San Donato Milanese, Italy

M. Frehner

Geological Institute, ETH Zurich, Sonneggstrasse 5,

8092 Zurich, Switzerland determined from line-length balancing. The model also clearly shows the lateral extension, the trend, and the variation in displacement along the principal faults. The reconstruction of horizons in 3D allows the investigation of cross-sections in any given direction. The 3D model is useful for developing and understanding how the internal nappe structures, namely folds and thrust faults, change along strike due to palaeogeographic and stratigraphic variations. Lateral stratigraphy variations correlate with different deformation responses of the nappe. Changes can occur either abruptly across transverse faults or in a more gradual manner.

Keywords Central Alps · Helvetic nappes ·

Säntis Thrust · 3D modelling · Line balancing ·

Depth validation with cave data

\section{Introduction}

Classic alpine studies have been investigating and visualizing the structural framework of complex nappe stacks with the help of 3D-like reconstructions such as physical series of 2D cross-sections, wooden block diagrams, or 3D plaster models. Astonishing examples of such models are displayed at the Focus Terra collection at the ETH Zurich. Among them is a 3D panelled model of Escher von der Linth and Heim (1905), which illustrates the lateral variations in the geological structures as seen in the Alpstein area in eastern Switzerland (Fig. 1).

Nowadays, due to recent advances in digital 3D and pseudo-3D modelling techniques and the diffusion of dedicated geo scientific information softwares (GSIS), geoscientists are able to generate detailed 3D models of 


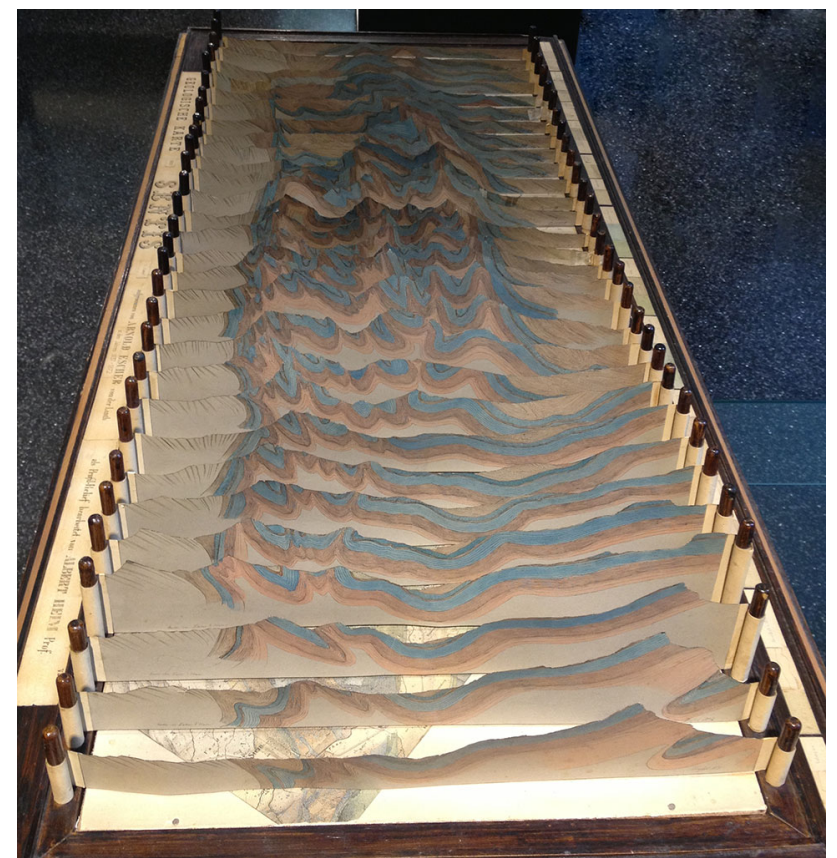

Fig. 1 Physical model of the Säntis area created by Albert Heim in 1905 based on original data from Arnold Escher von der Linth. The model consists of a collection of 2D cross-sections in a 3D array underlain by the geological map of the Säntis area. The model has a size of approximately $1 \times 2 \mathrm{~m}$ and is displayed in the ETH Focus Terra collection. The picture is taken looking towards the NE of the model along the strike of the structures. Light blue is the Schrattenkalk. The model shows at a glance the lateral variation in the internal structures along the mountain chain axis

complex geological settings (Tanner et al. 2003; Zanchi et al. 2009; Sala et al. 2013).

A wide range of research opportunities is offered by the use of such models:

- Investigation of specific structures and their spatial variations;

- identification of the processes involved in the formation of such structures;

- reconstruction of the deformation history of an area;

- visualization for didactical/teaching purposes, for example during classes of structural geology.

Our research focuses on the analysis of the Alpstein area in eastern Switzerland. This mountain range is part of the Säntis nappe, which is the highest nappe of the Helvetic nappe-stack. The latter is the fold-and-thrust belt on the northern margin of the central Swiss Alps (Pfiffner 1981). The nearly perfect outcrop conditions, combined with the exemplary intersection of formation boundaries with topography, make it a superb laboratory for structural geology. Since the pioneering work of Heim (1905) at the beginning of the 20th century, the area was mapped in detail (Eugster et al. 1982) and investigated in terms of deformation mechanisms (Groshong et al. 1984), structural evolution, and fold-thrust interaction (Funk et al. 2000; Pfiffner 1985, 1993, 2011). The restorations proposed so far are mostly two-dimensional palinspastic reconstructions, either in map or in cross-sectional view. A total displacement of the nappe was computed with the help of 2D palaeogeographic maps by Kempf and Pfiffner (2004), and Pfiffner $(2009,2011)$ and estimated as $95 \mathrm{~km}$ from the original position.

In this paper we present a three-dimensional model of an area representative of the Säntis nappe between Wildhaus and the Rhine Valley. In particular, the 3D model focuses on the frontal part of the Säntis nappe. The model is discussed in the light of lateral structural changes, fold-fault interaction, and influences of palaeogeographic features on the structural style. Additionally, cave data are projected into the model to validate some of the lithological boundaries at depth.

\section{Geologic setting of the Säntis area}

The Helvetic nappes represent a fold-and-thrust belt related to the collision between the European and the Adriatic plates. They comprise allochthonous sediments, spanning from Triassic to Paleogene, that were detached from the European passive margin at the beginning of the Oligocene along a basal thrust fault and transport over a distance of almost a hundred kilometres (Pfiffner 2011).

Internally, the nappes show a variety of complex structures, such as fault-propagation folds and fault-bend folds associated with thrust faults, and detachment folds, associated with areas with significant accumulations of weak sediments. Fold axial surfaces and thrust faults generally strike parallel to the trend of the mountain chain, but locally they are displaced by a number of prominent strikeslip faults, which cause variations in the internal structure of the nappes.

In the Säntis nappe, a sequence of Cretaceous to Paleogene calcareous formations is detached from its Jurassic substratum along the Säntis Thrust (Figs. 2, 3). From bottom to top, the most characteristic and dominant stratigraphic units are:

- The Öhrli Formation, which consists of two main members (Grasmück-Pfluger 1962): the Öhrli Marl (the main detachment horizon, of Berriasian age) and the Öhrli Limestone. The Öhrli Fm., up to $250 \mathrm{~m}$ thick, is represented by a fossiliferous, light-coloured limestone, often interrupted by a marly horizon rich in bioclasts and lithoclasts. Hardgrounds are often found at the top of the formation. 


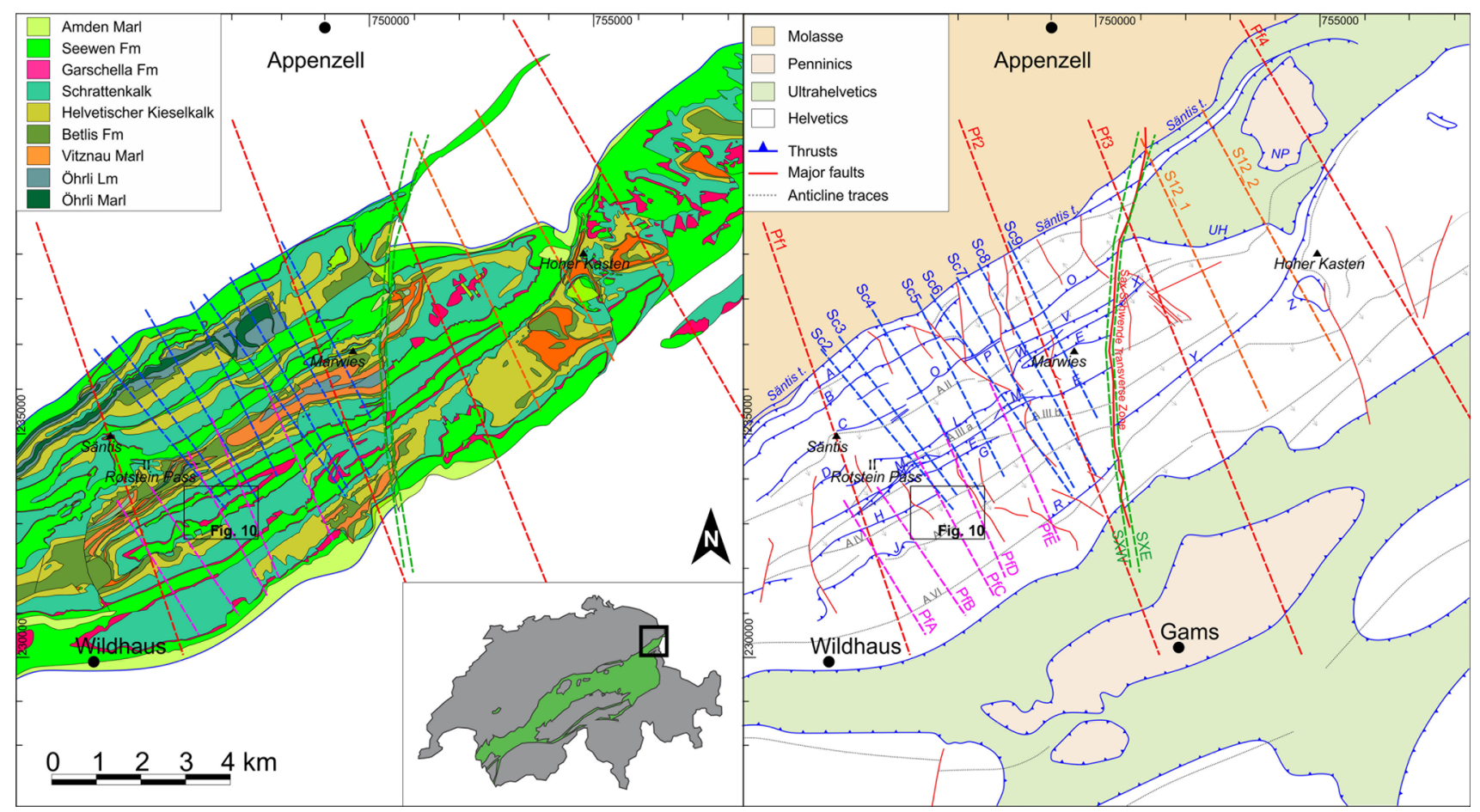

Fig. 2 Maps of the Alpstein area. Inset Helvetic nappes distribution (green) in Switzerland with the location of the study area. a Geological map of the study area with a simplified stratigraphy. b Simplified structural map of the study area. The cross-sections used in the model building process are shown in both $\mathbf{a}$ and $\mathbf{b}$ and labeled in (b). Arrows appearing with the anticline traces refer to the dip direction of the fold axial planes. Capital letters (e.g., $A, B, C$ ) refer to thrusts; capital " $A$ "s followed by a roman number (e.g., $A I, A I V$, etc.) refer to anticline traces. NP North Penninic nappe; $U H$ Ultrahelvetic nappe. Coordinates are given in the Swiss coordinate system CH1903
- Vitznau Marl (Valanginian; Burger and Strasser 1981): a $50 \mathrm{~m}$ thick limestone-marl alternation, at the base fossiliferous and clay-rich, evolving upward into sandrich and fossil-poor beds with abundant sedimentary structures.

- Betlis Formation (Valanginian; Burger and Strasser 1981): brown to blue-greyish limestone, well stratified in medium to thick beds. It reaches up to $90 \mathrm{~m}$ thickness. Toward the top, the formation becomes very similar to the Schrattenkalk and relatively poor in macrofossils, with the exception of regional coarse sand beds known as Pygurus Schist.

- Helvetischer Kiesekalk (Valanginian-Hauterivian; Funk 1969): light-coloured siliceous limestones and calcareous marls. The Helvetischer Kieselkalk mostly comprises bioclastic wackestones and packstones, rich in glauconite and pyrite and locally showing chert nodules. Regional beds with Echinoderm-breccias can be found at the top of the formation. The thickness of the formation can vary from 15 to $600 \mathrm{~m}$.

- Schrattenkalk (Early Barremian-Early Aptian; Bollinger 1988): up to $300 \mathrm{~m}$ thick bioclastic to oolithic limestone, seldom marly. The Schrattenkalk is the main formation making the rock walls and cliffs that are visible everywhere in the Alpstein region.

- Garschella Formation, also known as Helvetischer Gault (Aptian-Cenomanian; Föllmi and Ouwenhand 1987): a typical condensed section with variable lithologies, including glauconitic and apathitic sandstones, nodular limestones, sandy marls, and marly limestones. Many condensation horizons are present. The thickness is extremely variable, ranging from $\mathrm{cm}$ to a maximum of $100 \mathrm{~m}$.

- Seewen Formation (Cenomanian-Late Santonian; Bolli 1944): up to $200 \mathrm{~m}$ thick, well stratified micritic limestones, sometimes nodular, becoming marly and shaly toward the top of the formation.

- Amden Marl (Late Santonian-Campanian; OberhänsliLangenegger 1978): a laminated marly lutitic sequence.

The real stratigraphy includes a number of sub-units not mentioned here. For a complete overview, see Fig. 3a, where a complete lithostratigraphic column from Eugster et al. (1982) is shown.

On the geological map (Fig. 2a) it is possible to notice differences in the outcropping formations from northwest to 


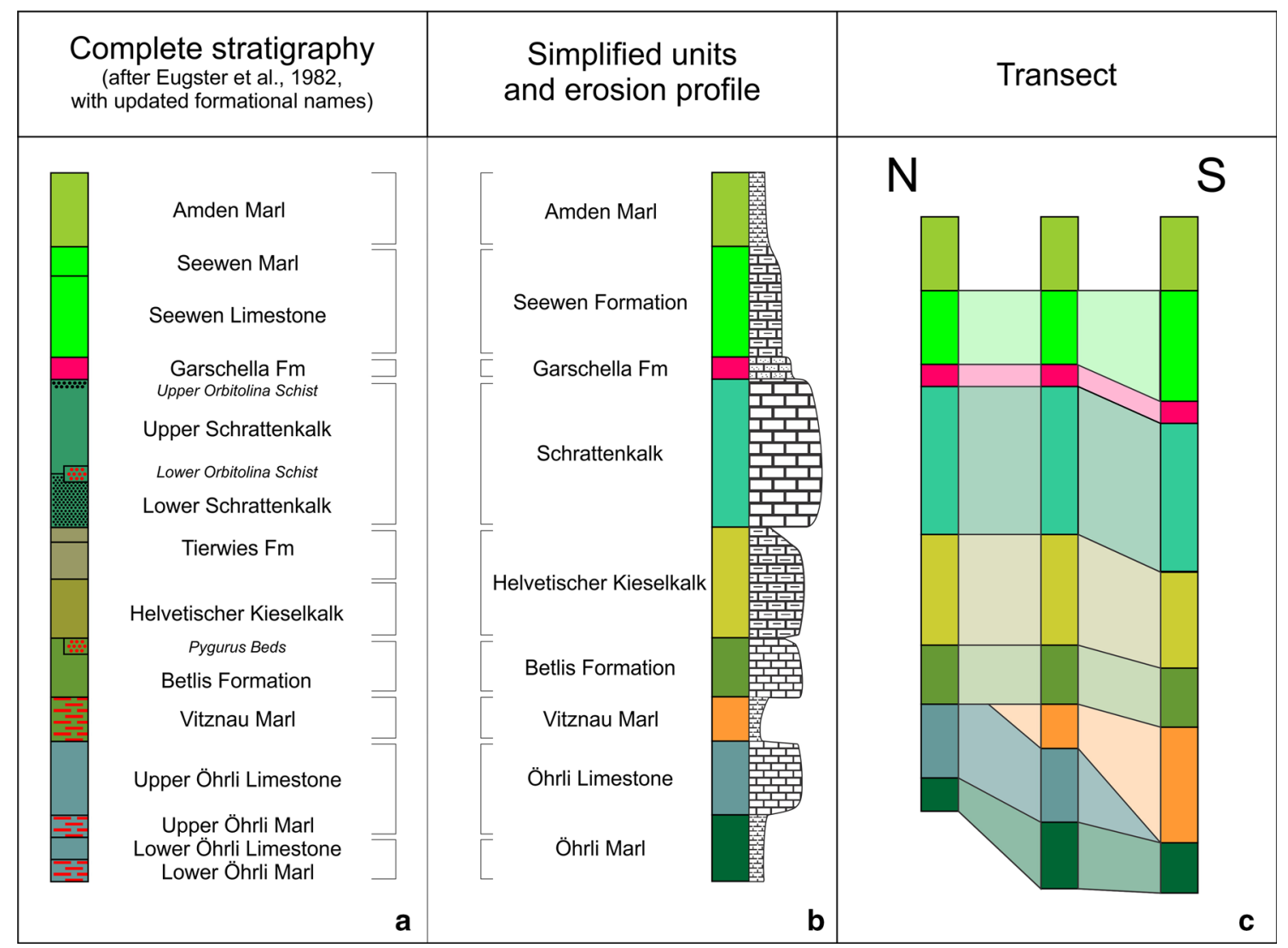

Fig. 3 Stratigraphy of the study area: a Complete stratigraphy as described in Eugster et al. (1982). b Simplified stratigraphy, grouping some of the formations into larger units and corresponding erosion profile. c North-south correlation schematically showing thickness and lateral variation of the stratigraphy. Most notable is the increase in thickness of the Vitznau Marl towards the south southeast with a stiffer and more homogeneous sequence of limestones in the NW, the interfingering with Vitznau Marls in the centre and the disappearance of the Öhrli Limestone and Öhrli Marl in the SE. In general, the lowermost marly units from Berriasian to lower Valanginian seem to be discontinuous across the area with the Öhrli Marl outcropping north and the Vitznau Marl outcropping south of the area of the Rotstein Pass (see Figs. 2, 3).

We reorganized the original stratigraphy into a simplified column (Fig. 3b), which aims at selecting the main horizons to be modeled and displayed in the 3D model, rather than grouping units with similar mechanical behavior. The simplified stratigraphy contains eight units corresponding to the top surface of the Öhrli Marl, Öhrli Limestone, Vitznau Marl, Betlis Formation, Helvetic Kieselkalk, Schrattenkalk, Garschella Formation, and Seewen Formation. The sedimentary sequence is folded in anticline-syncline pairs, mostly with axial surfaces striking-NE-SW with one exception: the big anticline of the Hoher Kasten, with an axial surface bending towards a strike of N30E.

The area is divided into two main blocks by the transverse Sax-Schwende Fault system. Smaller fault blocks are delimited by main thrust faults striking NE-SW and steeply dipping, transverse, strike-slip faults striking $\mathrm{N}-\mathrm{S}$ to NNW-SSE.

\section{Data collection}

To build the model, we used the pseudo 3D-modelling approach (Wilkerson et al. 1991; Cristallini and Allmendinger 2001). This modelling procedure consists in creating 3D surfaces by interpolating successive parallel crosssections.

The raw data used to generate the 3D model are five sets of cross-sections published between 1941 and the present day (Fig. 4a-f). They are taken from Schlatter (1941), Kempf (1966), Pfiffner in Funk et al. (2000) and Pfiffner (2011), except for 2 profiles specially constructed for this study. For a precise position of the cross sections, see Fig. 2 and Table 1.

Most of the cross-sections lack precise spatial references, for example the ones from Schlatter (1941) and Pfiffner (2011). It was therefore necessary to georeference 
them in ArcGIS with the help of a digital elevation model (DEM) from the Swiss Federal Office of Topography (Swisstopo), with a grid size of $10 \times 10 \mathrm{~m}$. The geological map of the Säntis was draped onto the DEM to help position the cross-sections with respect to the geology and topography. Generally, the cross-sections are straight transects oriented perpendicularly to the trend of the mountain chain (NNW-SSE), but a few of them are doglegged as deduced from the comparison with the topography (as in the case of the cross-sections of Kempf 1966, used in constructing those in Fig. 4b).

The five sets of cross-sections were constructed by five different authors, who all followed a different structural style. Therefore, the first step was to homogenize the structural style of the cross-sections, either by adapting them to a more accurate and recent geological map or by completely redrawing them, especially those with an uncertain position. The latter was done for the cross-sections of Schlatter (1941) and Pfiffner (2011), for which the provided map was not detailed enough to spatially constrain the sections.

The four longest cross-sections covering the whole area of the Säntis geological map sheet and running perpendicular to the strike of the chain (Pfiffner in Funk et al. 2000) constitute the back-bone of the model and set the scale of the model to a rectangular area of about $14 \times 16 \mathrm{~km}$. The gaps between them are filled, in the western part of the model, by eight cross-sections from Schlatter (1941) covering the frontal structures and five cross-sections from Pfiffner (2011) covering the southern folds and thrusts toward the Rhine valley. In the eastern part, due to a lack of data, we newly drew two new cross-sections in addition, to increase the level of detail of the constructed surfaces.

The cross-sections were validated by line-length balancing. The final cross-sections are shown in Fig. 4. Comparing the line length of the Schrattenkalk with the actual horizontal length of the Schrattenkalk allows the estimation of the bulk shortening stored in one cross-section; comparing different cross-sections then allows estimating the lateral variation of bulk shortening across the different crosssection sets (Table 2).

Additional data that is integrated into the model are cave geometries provided by the Speleological Group of Eastern Switzerland (OGH). We show in the discussion section how we used this data to validate the model in depth.

\section{Model building methodology}

For our reconstruction, we used the structural modelling software package Move 2012 from Midland Valley Ltd; the distinctive trait of this software is that it constructs triangular meshes from lines. The construction of the crosssections required tools available only within $2 D$ Move, yet the structural model itself was built in $3 D$ Move. Hence, we applied an integrated workflow combining 2D Move and $3 D$ Move to exchange the data between the $2 \mathrm{D}$ and the $3 \mathrm{D}$ environment.

First, the cross-sections were imported and digitized in 2D Move. Each lithological interface is at this point represented by polylines, defined by a number of points that will dictate the final triangular mesh size of the surfaces. The triangular mesh size strictly depends on the desired resolution for the reconstructed surfaces; would be necessary to keep in mind that an excessive number of points on the polylines leads to a dense tessellation and heavier computation for the software, especially in case of hardware limitations. The reconstructed lithological interface lines are then cross-checked with respect to line length and thickness. Some degree of freedom in the thickness of each formation is allowed due to known thickness variations in the stratigraphy (Fig. 3b). Afterwards, the cross-sections are sent to $3 D$ Move.

In $3 D$ Move the segments belonging to the same stratigraphic horizon can now be linearly interpolated between cross-sections to generate triangular meshed 3D surfaces (Fig. 5). We first reconstructed the discontinuity elements such as faults and thrust faults. This way we were aware of areas where it is necessary to introduce a displacement in the horizons. The faults that lie between cross-sections and are therefore not represented in the cross-sections were generated from the vectorial elements of the Swisstopo geological dataset (Vectorial map 1115). We digitized the fault traces on the map and then filtered them based on their extent: we only kept the longest features in the model; shorter fault segments with no significant displacement were erased. The remaining faults were then draped onto the DEM to add the elevation information. Finally, we obtained the fault surfaces from the orientation analysis of these outcrop traces using the geological contact analysis (also known as ribbon technique: Fernández 2005; Fernández et al. 2009). This technique allows determining the orientation of a planar feature given a set of points or lines with their known positions in the 3D space; the method determines the best-fit plane through such elements (Fernández 2005).

The cross-sections stem from different authors. Even though they were cross-checked and unified in terms of structural style, some issues can arise when fitting surfaces from one cross-section to the other. This implies continuous interactions and updates of the cross-sections while creating the model and tuning the bed thickness in order to generate a best-fitting plane. During this procedure it is quite important to keep track of the line-length balancing, 
which is not always possible to fully respect. In some cases not all of the segments have the same length.

Particular care must be taken when generating surfaces when faults run parallel to the cross-sections, or more generally with orientations perpendicular to the direction of interpolation. Faults have to be modeled taking care of their dip angle, azimuth, and the amount of displacement. Knowing the general trend of the surfaces on both sides of the fault, the modeler can proceed in two ways to complete the horizons: (a) extruding a surface from the cross-section segment with a trend parallel to the fold axis toward the fault plane, then trimming away the parts cutting the fault plane, or (b) tracing an expected Allan line when the desired extrusion is creating a surface that is hard to trim because the fault surface is smaller than the final surface. An Allan line is a projection of the horizon on the fault surface (Allan, 1989) so that interpolation can be performed between the cross-section and this 'artificial' line on the fault.

\section{Results and interpretation}

Once all of the faults, thrust faults, and stratigraphic surfaces are generated, the model is complete (Fig. 6). The 3D model is available for download in Online Resource 1 attached to the online version of this journal and can be visualized using the free MoveViewer software available at http://www.mve.com. Please refer to Online Resource 1 for a description on how to handle the dataset.

The first observation that can be made in the model is that it comprises two separate blocks, W and E, separated by the Sax-Schwende Fault zone. Both blocks show a distinct structural framework and style as described below (Sect. 5.2).

\subsection{Stratigraphic surfaces}

The final surfaces are generally smooth, with some minor gaps due to tectonic and interpolation artefacts. As an example, we show the Schrattenkalk top surface with and without faults in Fig. 7. The western part of the surface (i.e., west of Sax-Schwende Fault) is highly deformed and strongly affected by thrusting. At the center of the model (Fig. 7a) it is possible to identify the Marwies Anticline, which is underlined by the folded Rotstein Pass Thrust. The eastern part is more gently folded and a recumbent fold is developing from W (Saxer Lücke) to E (Hoher Kasten) with increasing amplitude and tilting of the axial surface. All surfaces are covering the whole model except for two: the Top Vitznau Marl, which is limited to the south of thrust E in the Western block (Rotstein Pass Thrust) and
Fig. 4 Set of cross-sections used for the 3D model construction. All cross-sections are seen from the NE (as in Fig. 1, precise orientations of cross-sections in degrees from North are given by the arrow in each upper-right corner). Cross-section names of Fig. 2 are given in each lower-right corner. The location of each cross-section is shown in Fig. 2. Each horizon represents the top surface of a unit; the colors of the horizons follow the stratigraphic scheme given in Fig. 2. a Set of cross-sections (Pf1-Pf4) modified from Pfiffner in Funk et al. (2000). b Set of cross-sections (PfA-PfE) modified from Pfiffner (2011), partly based on Kempf (1966). c Set of cross-sections (Sc2-Sc5) modified from Schlatter (1941). d Set of cross-sections (Sc6-Sc9) modified from Schlatter (1941) (continued). e Set of cross-sections (S12-2 and S12-2) prepared for this work. f Dog-legged cross-section set $(2 \times)$ modified from Pfiffner (1985). These cross-sections were only published later in Pfiffner (2011)

the Top Öhrli Limestone, which disappears south of the anticline VI (Fig. 2b).

\subsection{Structural surfaces and observed style}

The basal Säntis Thrust covers the entire model area. It is cut by the Sax-Schwende Fault that separates it in two parts, the western part of the thrust being higher than the eastern part. A discussion of the variable offset along this fault is given in Pfiffner (2011). Generally, the offset along the Sax-Schwende Fault raised the western block in the south, whereas the horizontal, right-lateral displacement becomes more prominent to the north. The Säntis Thrust is also gently folded in its frontal part (NNW) as a syncline and in the rear (SSE) as an anticline.

The western block (Fig. 8) presents imbricated thrusts striking SW-NE with a mostly NW vergence. As an exception, two back-thrusts with a SE vergence exist in the area north of the Seealpsee $(\mathrm{O})$ and in the Kreuzberg area, in the South (R). The most persistent thrust system besides the basal Säntis Thrust is the Rotstein Pass Thrust that further divides the western block into two smaller subareas (Fig. 8, 9). The front of this thrust is folded in the Marwies area as anticline-syncline pair (Fig. 8), with a consequent doubling of the stratigraphic sequence as seen in outcrop in the Marwies north wall. The Rotstein Pass Thrust is bounded on both sides by a series of small imbricates with similar vergence; we define the combination of small imbricates and main thrust blocks as the Rotstein Pass Thrust Zone.

The eastern block (east of Sax-Schwende Fault) shows less thrusting but includes a $\mathrm{km}$-scale folded Ultrahelvetic thrust in the North and the North Penninic Thrusts in the South (Fig. 2b). The southern part evolves toward the East (toward Hoher Kasten) into a recumbent fold. During the construction of transect S12-2 (Fig. 4e) a tectonic window immediately east of the Hoher Kasten was studied in the field to improve the general understanding of the area. Situations like the interfingering of the 
a

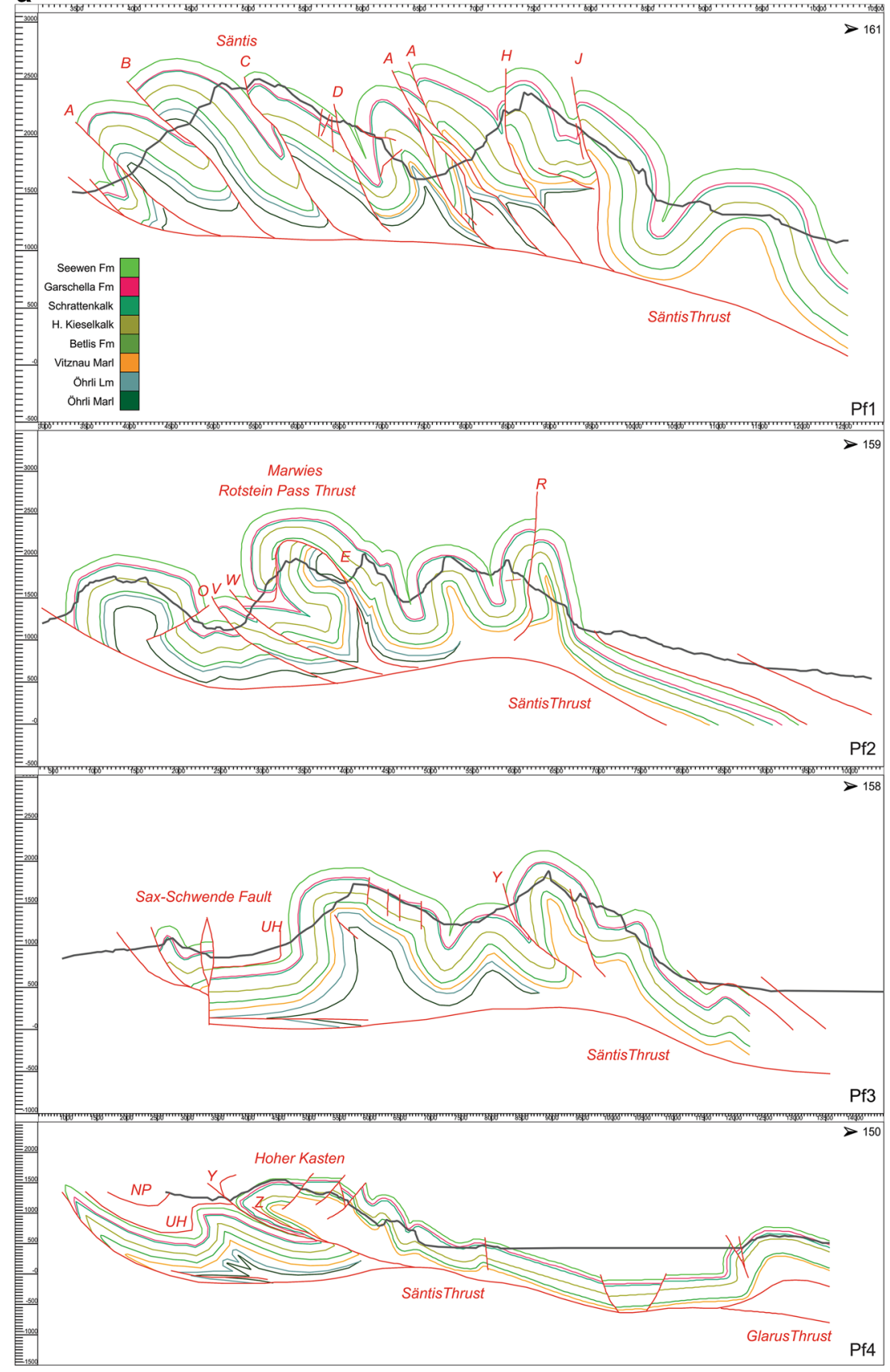

b

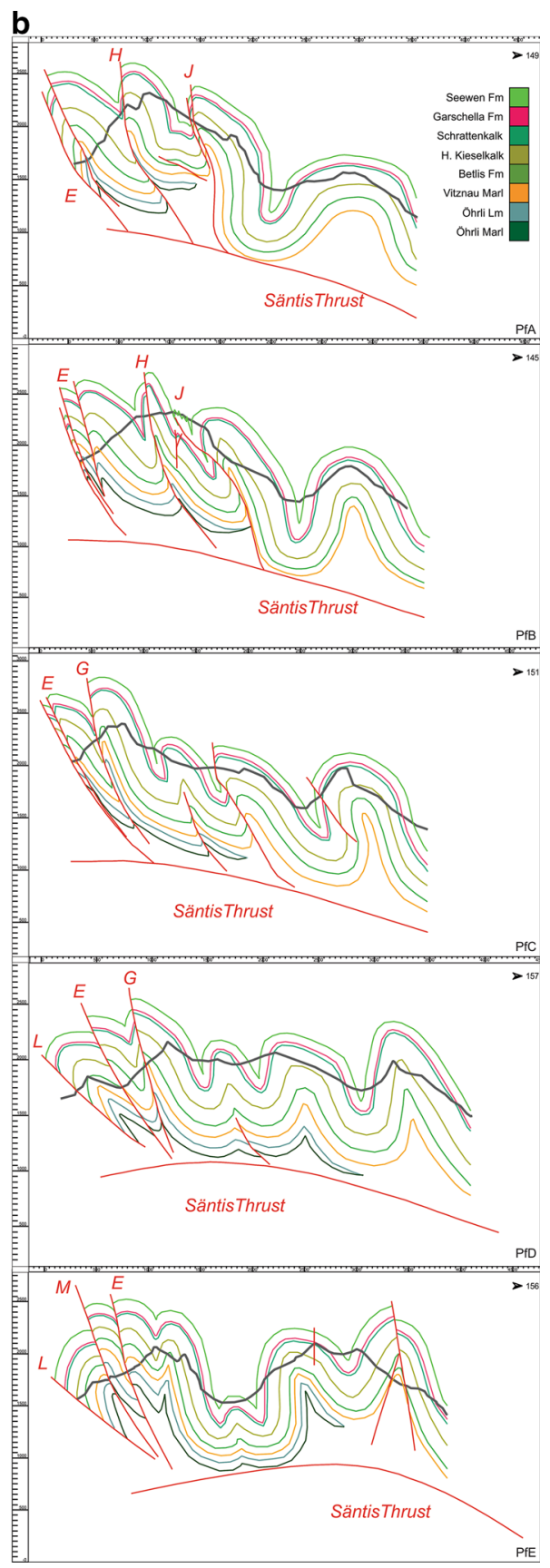

Vitznau Marls and the disappearing Öhrli Limestone in the south were modeled considering the change in structural style at the surface (Fig. 2). In defining the boundaries of these units, the Rotstein Pass Thrust plays an important role. In fact the Vitznau Marl thins out immediately north of the first anticline north of the Rotstein Pass Thrust Zone in the western block (Fig. 9a), while in the eastern block the same unit spreads across the whole block (Fig. 9a). The Öhrli Limestone and the Vitznau Marl coexist at the Rotstein Pass Thrust Zone, then the Öhrli Limestone tongue disappears south of the
Rotstein Pass Thrust Zone and a change in structural style is marked by the presence of open folds starting south of anticline V and VI (Fig. 9b).

\section{Discussion}

6.1 Depth validation with information from caves

The structural model is based solely on interpreted crosssections. Depth constraints like seismic lines or deep wells, 
Fig. 4 continued

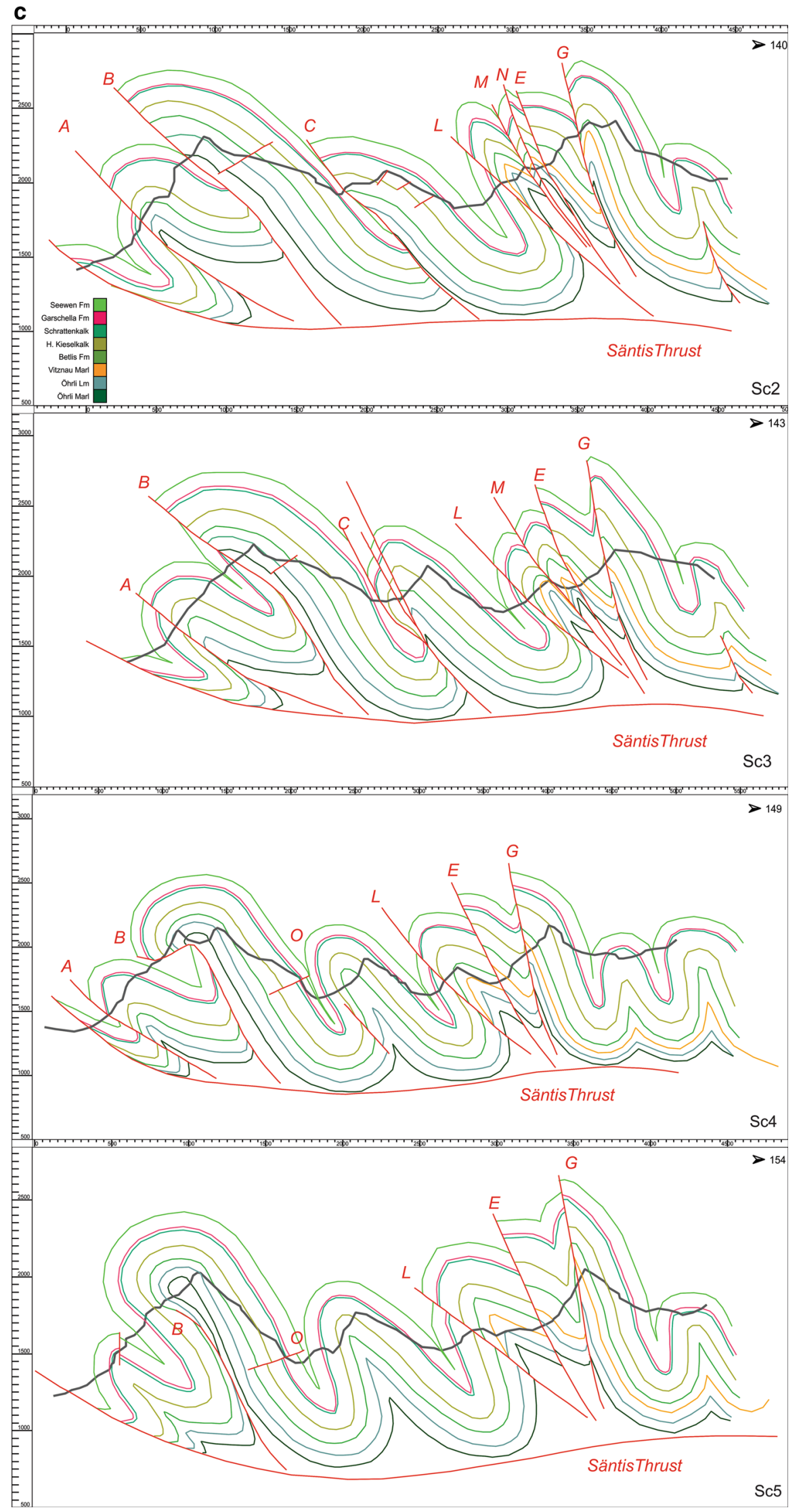


Fig. 4 continued

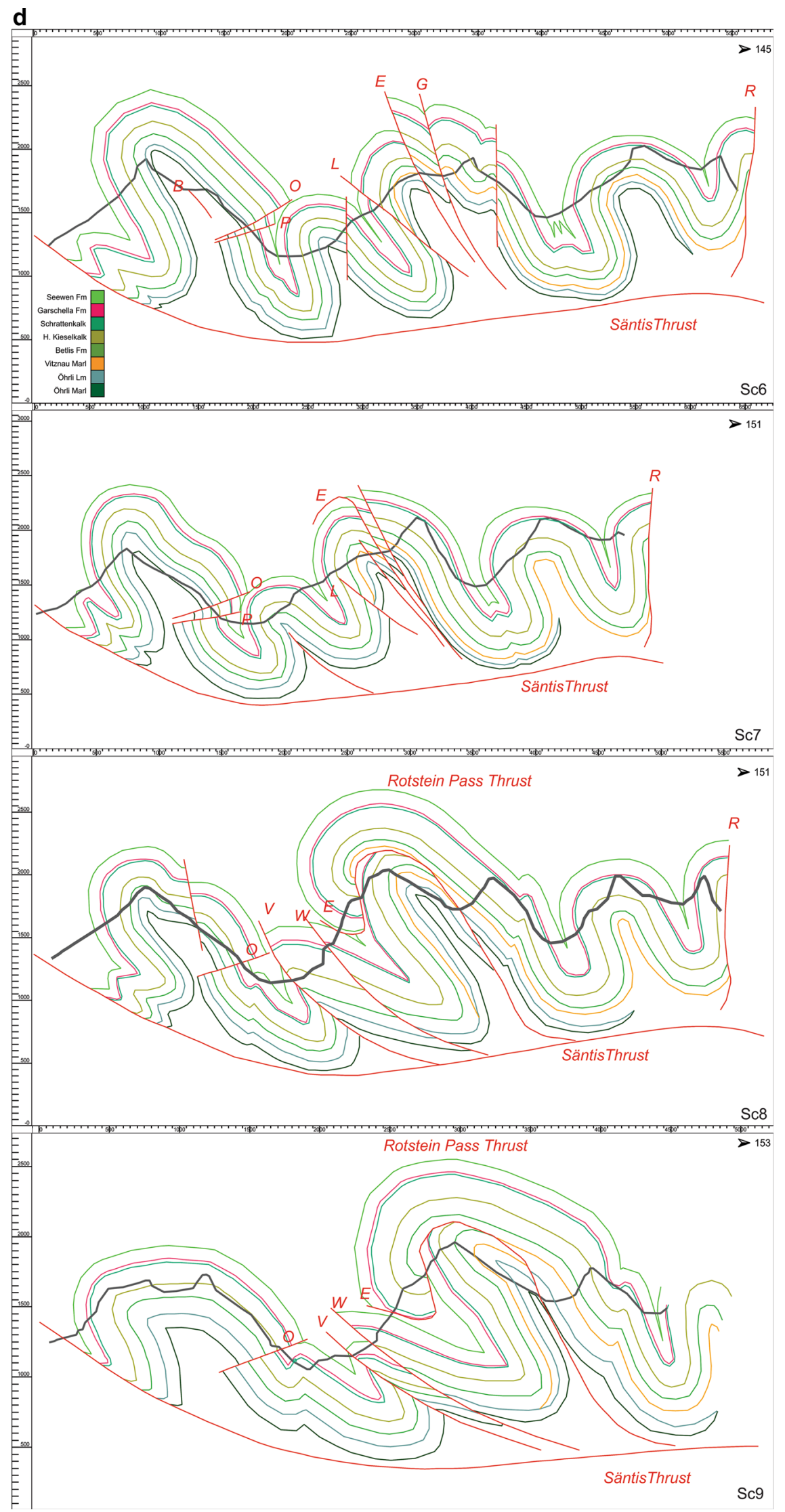


Fig. 4 continued
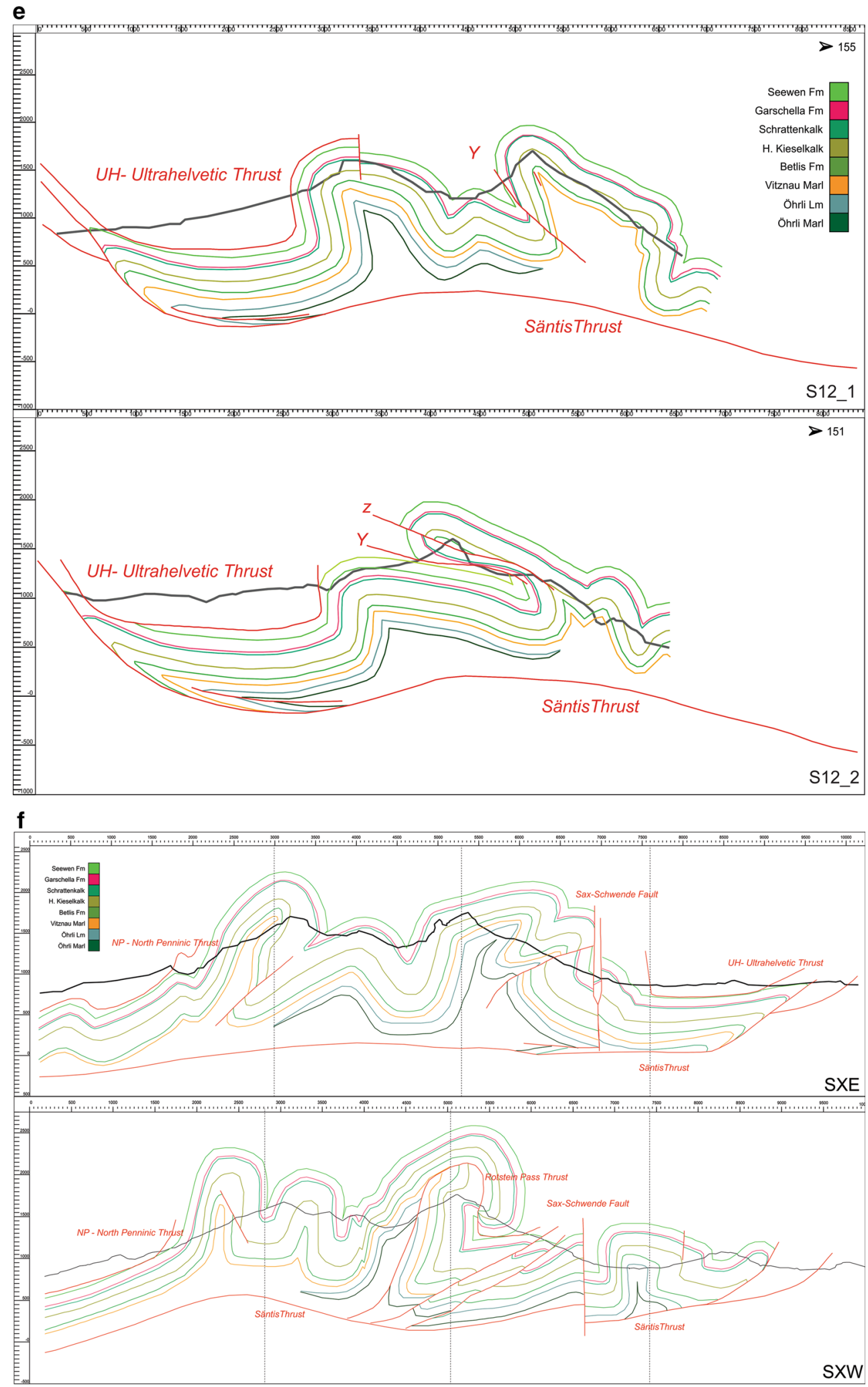

which would allow a more precise interpretation and a control of the stratigraphy at depth, are not available. This can lead to some uncertainties, for example the depth to the detachment (Säntis Thrust) or the exact extension of the lower marly intervals (Öhrli and Viznau Marl). Additional information on subsurface geological boundaries can 
Table 1 Summary of sets of cross-sections with spatial references and sources

\begin{tabular}{|c|c|c|c|c|c|c|c|c|c|c|}
\hline \multirow{2}{*}{$\begin{array}{l}\text { Cross- } \\
\text { section } \\
\text { names }\end{array}$} & \multirow{3}{*}{$\begin{array}{l}\text { Source } \\
\\
\text { Pfiffner in Funk et al. } \\
\text { (2000), Table 1 }\end{array}$} & \multirow{2}{*}{$\begin{array}{l}\text { Originally } \\
\text { georeferenced } \\
(\mathrm{Y} / \mathrm{N})\end{array}$} & \multicolumn{2}{|c|}{$\begin{array}{l}\text { Original } X Y \text { coordinates } \\
L(\mathrm{~m})\end{array}$} & \multicolumn{2}{|c|}{$\begin{array}{l}\text { Original } X Y \text { coordinates } \\
R(\mathrm{~m})\end{array}$} & \multicolumn{2}{|c|}{$\begin{array}{l}\text { Top and } \\
\text { bottom } \\
\text { elevation }(m)\end{array}$} & \multirow{2}{*}{$\begin{array}{l}\begin{array}{l}\text { length of } \\
\text { SK }(\mathrm{m})\end{array} \\
6,521.19\end{array}$} & \multirow{2}{*}{$\begin{array}{l}\begin{array}{l}\text { Section } \\
\text { length } \\
(\mathrm{m})\end{array} \\
6,824.08\end{array}$} \\
\hline & & & 742,500 & 239,700 & 745,800 & 230,000 & 2,500 & 0 & & \\
\hline Pf2 & & $\mathrm{Y}$ & 746,900 & 242,000 & 751,400 & 230,000 & 2,500 & 0 & $8,269.32$ & $9,847.62$ \\
\hline Pf3 & & $\mathrm{Y}$ & 749,800 & 242,000 & 754,600 & 230,000 & 2,000 & 0 & $7,019.18$ & $7,531.13$ \\
\hline Pf4 & & $\mathrm{Y}$ & 754,500 & 242,000 & 760,000 & 232,500 & 2,000 & $-1,000$ & $12,327.48$ & $12,683.86$ \\
\hline PfA & Pfiffner (2011), p 101 & Partly & $744,462.42$ & $233,224.81$ & $746,153.12$ & $230,454.62$ & 2,500 & 400 & $3,439.56$ & $3,538.96$ \\
\hline PfB & (after Kempf 1966) & Partly & $745,063.36$ & $233,770.85$ & $747,051.05$ & $230,883.57$ & 2,500 & 700 & $3,513.12$ & $3,593.81$ \\
\hline PfC & & Partly & $746,036.37$ & $234,307.29$ & $747,691.34$ & $231,318.82$ & 2,800 & 600 & $3,617.76$ & $3,708.6$ \\
\hline PfD & Pfiffner (2011), p 101 & Partly & $746,664.75$ & $234,785.13$ & $747,976.03$ & $231,718.07$ & 2,600 & 900 & $3,691.94$ & $3,862.93$ \\
\hline PfE & & Partly & $747,716.08$ & $235,828.36$ & $749,156.74$ & $232,566.04$ & 2,500 & 900 & $3,665.28$ & $3,806.95$ \\
\hline $\mathrm{Sc} 2$ & Schlatter (1941) & $\mathrm{N}$ & $743,961.34$ & $236,661.52$ & $746,772.54$ & $233,261.61$ & 2,500 & 1,000 & $4,411.6$ & $4,589.49$ \\
\hline $\mathrm{Sc} 3$ & & $\mathrm{~N}$ & $744,301.99$ & $237,010.77$ & $746,856.35$ & $233,583.24$ & 2,300 & 800 & $4,205.2$ & $4,679.56$ \\
\hline $\mathrm{Sc} 4$ & & $\mathrm{~N}$ & $744,987.06$ & $237,677.68$ & $747,505.9$ & $233,427.40$ & 2,272 & 550 & $5,033.71$ & $5,387.94$ \\
\hline Sc5 & & $\mathrm{N}$ & $746,026.35$ & $237,802.56$ & $747,914.42$ & $234,001.02$ & 2,300 & 500 & $3,956.57$ & $4,532.94$ \\
\hline Sc6 & & $\mathrm{N}$ & $746,261.30$ & $238,090.43$ & $749,444.77$ & $233,562.87$ & 2,200 & 400 & $5,233.39$ & $5,675.34$ \\
\hline Sc7 & & $\mathrm{N}$ & $746,847.62$ & $238,469.31$ & $749,482.87$ & $233,753.37$ & 2,140 & 0 & $5,155.89$ & $5,644.67$ \\
\hline $\mathrm{Sc} 8$ & & $\mathrm{~N}$ & $747,322.40$ & $238,781.91$ & $750,002.63$ & $233,998.23$ & 2,100 & 600 & $4,943.75$ & $5,543.93$ \\
\hline $\mathrm{Sc} 9$ & & $\mathrm{~N}$ & $748,033.61$ & $239,208.41$ & $750,023.28$ & $235,271.40$ & 2,000 & 0 & $4,017.83$ & $4,476.81$ \\
\hline S12_1 & Sala this work & $\mathrm{Y}$ & $750,991.72$ & $241,560.29$ & $753,826.74$ & $235,465.07$ & 2,000 & 0 & $6,416.17$ & $7,101.88$ \\
\hline S12_2 & & $\mathrm{Y}$ & $755,466.37$ & $236,589.30$ & $752,493.33$ & $241,981.10$ & 2,000 & 0 & $5,963.61$ & $6,435.27$ \\
\hline SW1 & Pfiffner (2011) & Partly & $750,928.71$ & $241,730.56$ & 750,370 & 239,202 & 2,000 & -500 & $1,352.16$ & $2,194.05$ \\
\hline SW2 & & Partly & $750,369.90$ & $239,202.30$ & $750,196.70$ & $236,834.00$ & 2,000 & -500 & $2,361.95$ & $2,380.95$ \\
\hline SW3 & & Partly & $750,196.70$ & $236,834.00$ & $750,351.60$ & $234,636.30$ & 2,000 & -500 & $2,233.6$ & $2,242.82$ \\
\hline SW4 & & Partly & $750,351.60$ & $234,636.40$ & $750,751.30$ & $232,007.70$ & 2,000 & -500 & $2,672.41$ & $2,672.41$ \\
\hline SE1 & Pfiffner (2011) & Partly & $751,226.55$ & $241,549.15$ & $750,861.42$ & $232,055.88$ & 2,000 & -500 & $1,666.71$ & $2,579.73$ \\
\hline SE2 & & Partly & $750,535.46$ & $239,194.02$ & $750,338.08$ & $236,859.86$ & 2,000 & -500 & $2,290.5$ & $2,309.62$ \\
\hline SE3 & & Partly & $750,337.56$ & $236,858.80$ & $750,503.14$ & $234,587.85$ & 2,000 & -500 & $2,267.45$ & $2,275.57$ \\
\hline SE4 & & Partly & $750,501.82$ & $234,587.85$ & $750,859.71$ & $232,058.60$ & 2,000 & -500 & $2,796.21$ & $2,825.41$ \\
\hline
\end{tabular}

nevertheless be obtained from unusual data sources such as caves and from hydrogeological models. In fact, the Alpstein is rich in caves and some of them extend to depths of almost 1,000 $\mathrm{m}$ below surface. In the Zwingli Pass area, there are four large cave systems with an extension of up to $1,000 \mathrm{~m}$ and crossing at least two lithological boundaries. These caves are the Häxloch, the Schacht-Z7, the Huldrychhöhle and the Schneehöhle (Fig. 10). Two other long karstic systems can be found in the area of the Säntis and the Öhrli peaks. A single long system is known in the eastern part of the model, but it has not been mapped in detail, so it was not possible to implement it into our model.

The Speleological Group of Eastern Switzerland (Ostschweizerische Gesellschaft für Höhlenforschung-OGH) provided digital cave maps, containing distances and directions (slope and azimuth) between reference points along the cave, which were measured with a laser level tool. The files were imported into the mathematic software suite Matlab (Mathworks Inc.) and the absolute coordinates of the reference points were calculated starting from the entrance point, where a GPS measurement is available. The absolute 3D coordinates of these cave data were then imported in our Move model to visualize their intersection with the lithological interfaces.

Our final model predicts that the caves cross at least one lithological interface (Fig. 11). The Häxloch cave opens in the Schrattenkalk but continues mostly in the Helvetischer Kieselkalk and the Betlis Formation in its deeper parts (Fig. 11a). The Huldrychhöhle opens in the Seewen Formation, crossing the Garschella Formation and ending in the Schrattenkalk (Fig. 11b). The Schacht-Z7 cave mostly 
Table 2 Cumulative formation lengths for each cross-section (Fig. 4) with computed stretch and bulk shortening

\begin{tabular}{|c|c|c|c|c|c|c|c|c|c|c|c|}
\hline $\begin{array}{l}\text { Cross } \\
\text { section }\end{array}$ & $\begin{array}{l}\text { Total length } \\
\text { SK }(m)\end{array}$ & SW & G & SK & KK & $\mathrm{BE}$ & VM & OK & $\mathrm{OM}$ & $\begin{array}{l}\text { Stretch } \\
(\%)\end{array}$ & $\begin{array}{l}\text { Bulk } \\
\text { shortening }(\%)\end{array}$ \\
\hline Pf1 & 6521.19 & 10911.72 & 12603.66 & 12792.85 & $12,642.5$ & $12,604.33$ & $9,114.92$ & $8,188.73$ & $8,070.38$ & 50.98 & 49.02 \\
\hline Pf2 & $8,269.32$ & $14,276.07$ & $15,937.87$ & $16,079.16$ & $16,197.46$ & $15,882.22$ & $9,757.99$ & $8,142.16$ & $7,535.64$ & 51.43 & 48.57 \\
\hline Pf3 & $7,019.18$ & $10,158.21$ & $10,702.15$ & $10,765.74$ & $10,863.1$ & $10,393.88$ & $10,126.28$ & $6,206.25$ & $5,379.1$ & 65.20 & 34.80 \\
\hline Pf4 & $12,327.48$ & $16,983.26$ & $17,186.75$ & $17,277.71$ & $16,103.61$ & $16,124.74$ & $16,015.53$ & $4,953.67$ & $5,007.6$ & 71.35 & 28.65 \\
\hline PfA & $3,439.56$ & $5,733.12$ & $5,872.47$ & $5,980.68$ & $6,146.04$ & $6,173.33$ & $5,981.81$ & $2,036.73$ & $1,529.22$ & 57.51 & 42.49 \\
\hline PfB & $3,513.12$ & $7,004.63$ & $7,240.61$ & $7,281.27$ & $6,849.53$ & $6,612.12$ & $6,192.36$ & $2,422.05$ & $2,419.51$ & 48.25 & 51.75 \\
\hline PfC & $3,617.76$ & $6,793.88$ & $6,882.25$ & $6,947.46$ & $6,857.42$ & $6,773.47$ & $6,391.68$ & $2,729.97$ & $2,084.61$ & 52.07 & 47.93 \\
\hline PfD & $3,691.94$ & $6,530.32$ & $6,684.47$ & $6,669.84$ & $6,381.89$ & $6,125.05$ & $5,734.33$ & $3,491.66$ & $3,211.54$ & 55.35 & 44.65 \\
\hline PfE & $3,665.28$ & $6,614.99$ & $6,699.59$ & $6,760.32$ & $6,803.58$ & $6,807.66$ & $6,642.34$ & $4,592.35$ & $4,586.76$ & 54.22 & 45.78 \\
\hline $\mathrm{Sc} 2$ & $4,411.6$ & $9,731.13$ & $10,241.91$ & $10,290.6$ & $10,038.98$ & $9,225.12$ & $3,498.09$ & 8,910 & $8,646.01$ & 42.87 & 57.13 \\
\hline $\mathrm{Sc} 3$ & $4,205.2$ & $9,670.78$ & $11,164.21$ & $11,101.8$ & $10,388.56$ & $9,321.77$ & $3,323.75$ & $8,832.51$ & $7,913.64$ & 37.88 & 62.12 \\
\hline $\mathrm{Sc} 4$ & $5,033.71$ & $11,707.21$ & $11,903.87$ & $11,802.45$ & $11,510.07$ & $11,057.9$ & $4,320.93$ & $8,893.97$ & $7,807.3$ & 42.65 & 57.35 \\
\hline Sc5 & $3,956.57$ & $9,806.36$ & $10,522.58$ & $10,454.74$ & $10,335.51$ & $10,157.64$ & $3,286.92$ & $8,434.16$ & $7,306.25$ & 37.84 & 62.16 \\
\hline Sc6 & $5,233.39$ & $11,777.5$ & $12,363.38$ & $12,399.21$ & $12,211.53$ & $11,760.7$ & $5,113.68$ & $10,603.81$ & $10,385.84$ & 42.21 & 57.79 \\
\hline $\mathrm{Sc} 7$ & $5,155.89$ & $11,438.29$ & $12,486.15$ & $12,428.5$ & $12,282.49$ & $12,048.21$ & $7,950.3$ & $9,167.2$ & $8,763.26$ & 41.48 & 58.52 \\
\hline $\mathrm{Sc} 8$ & $4,943.75$ & $11,562.5$ & $13,121.72$ & $13,047.79$ & $13,148.49$ & $12,266.72$ & $6,878.48$ & $9,334.87$ & $9,145.5$ & 37.89 & 62.11 \\
\hline $\operatorname{Sc} 9$ & $4,017.83$ & $9,350.41$ & $10,695.6$ & $10,748.57$ & $11,148.36$ & $10,583.08$ & $4,546.83$ & $8,054.53$ & $7,434.86$ & 37.38 & 62.62 \\
\hline S12_1 & $6,416.17$ & $9,620.5$ & $9,775.94$ & $9,781.05$ & $9,851.98$ & $9,776.99$ & $9,680.99$ & $6,058.94$ & $5,367.44$ & 65.60 & 34.40 \\
\hline S12_2 & $5,963.61$ & $8,632.64$ & $10,093.08$ & $10,138.74$ & $8,913.84$ & $8,057.35$ & $7,737.75$ & $5,039.57$ & $4,476.32$ & 58.82 & 41.18 \\
\hline SW1 & $1,352.16$ & $1,777.3$ & $1,833.6$ & $1,858.84$ & $1,517.15$ & $1,157.05$ & - & 428.22 & 253.09 & 53.26 & 46.74 \\
\hline SW2 & $2,361.95$ & $5,428.38$ & $6,183.72$ & $6,300.83$ & $5,602.89$ & $4,693.49$ & - & $3,407.46$ & $2,470.5$ & & \\
\hline SW3 & $2,233.6$ & $3,333.27$ & $3,708.82$ & $3,779.27$ & $5,121.66$ & $5,846.54$ & $5,101.29$ & $4,115.06$ & $3,531.57$ & & \\
\hline SW4 & $2,672.41$ & $4,008.43$ & $4,235.6$ & $4,245.66$ & $4,141.06$ & $3,843.58$ & $4,090.76$ & - & - & & \\
\hline SW (total) & $8,620.12$ & $14,547.38$ & $15,961.74$ & $16,184.6$ & $16,382.76$ & $15,540.66$ & $9,192.05$ & $7,950.74$ & $6,255.16$ & & \\
\hline SE1 & $1,666.71$ & $1,954.76$ & $1,762.15$ & $1,731.43$ & $1,466.07$ & $1,368.71$ & $1,263.68$ & 741.98 & - & 70.70 & 29.30 \\
\hline SE2 & $2,290.5$ & $3,006.87$ & $3,471.33$ & $3,529.21$ & $3,862.14$ & $3,984.19$ & $4,027.78$ & $4,564.9$ & $3,629.59$ & & \\
\hline SE3 & $2,267.45$ & $3,322.99$ & $3,676.77$ & $3,751.19$ & $3,952.59$ & $3,693.87$ & $3,379.58$ & $3,031.2$ & $2,709.8$ & & \\
\hline SE4 & $2,796.21$ & $3,697.36$ & $3,759.68$ & $3,748.36$ & $4,574.82$ & $5,004.76$ & $5,318.31$ & - & - & & \\
\hline SE (total) & $9,020.87$ & $11,981.98$ & $12,669.93$ & $12,760.19$ & $13,855.62$ & $14,051.53$ & $13,989.35$ & $8,338.08$ & $6,339.39$ & & \\
\hline
\end{tabular}

$S W$ Seewen formation, $G$ Garschella formation, $S K$ Schrattenkalk, $K K$ Helvetischer Kieselkalk, $B E$ Betlis formation, $V M$ Vitznau Marl, $O K$ Öhrli limestone, $O M$ Öhrli Marl

follows the Schrattenkalk, crossing the Garschella Formation and posssibly ending in the Seewen Formation (Fig. 11c). The Schneehöhle develops mostly in the Schrattenkalk, but a branch crosses the boundary with the Helvetischer Kieselkalk.

The latest cave survey conducted by OGH revealed the geology of some caves at smaller scale, confirming some of the predictions of our model. The model can give a rough idea of the geological formations crossed by a cave. However, the model scale can be too large for precise predictions on the scale of a cave. Problems arise when the caves developed along tectonic lineaments, as is the case of the Häxloch, where the large scale resolution of the model does not show the effect of a normal fault detected by the speleologists in the cave.

\subsection{Shortening estimate}

From line-length balancing, comparing the constructed with unfolded section (Table 2), it is possible to estimate the amount of shortening in each cross-section (Fig. 12; Table 2). We observe a sudden change in shortening across the Sax-Schwende Fault, with higher shortening values in the West. The long cross-sections from Pfiffner in Funk et al. (2000) show values of around 50\% shortening for the western block and around $30 \%$ 
Fig. 5 Example of surface construction process. a Crosssections $P f C$ and $P f A$, which were digitized in $2 D$ Move and imported in $3 D$ Move, are shown in a 3D view. b Traces of bedding or faults in adjacent cross-sections, which are interpreted to be part of the same structure (red and green bold segments in a), are connected by interpolation
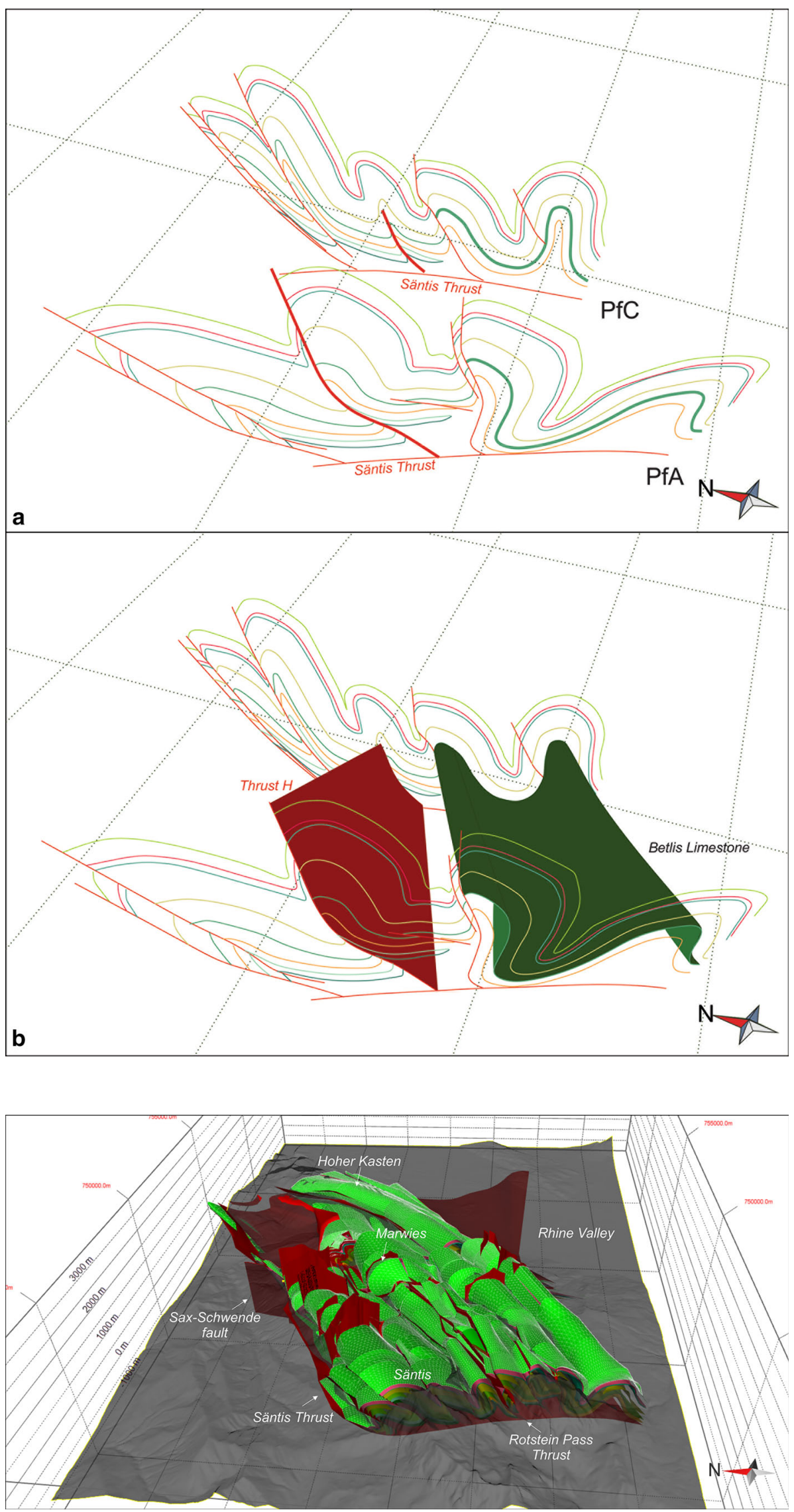

Fig. 6 Oblique perspective view of the complete 3D structural model, looking towards E, showing the fault surfaces (red) and lithological horizons. The topography (DEM) in transparent gray cuts through the model. The model is available for download from Online Resource 1 on the online version of the journal and can be visualized using the free MoveViewer software available at http://www.mve.com 


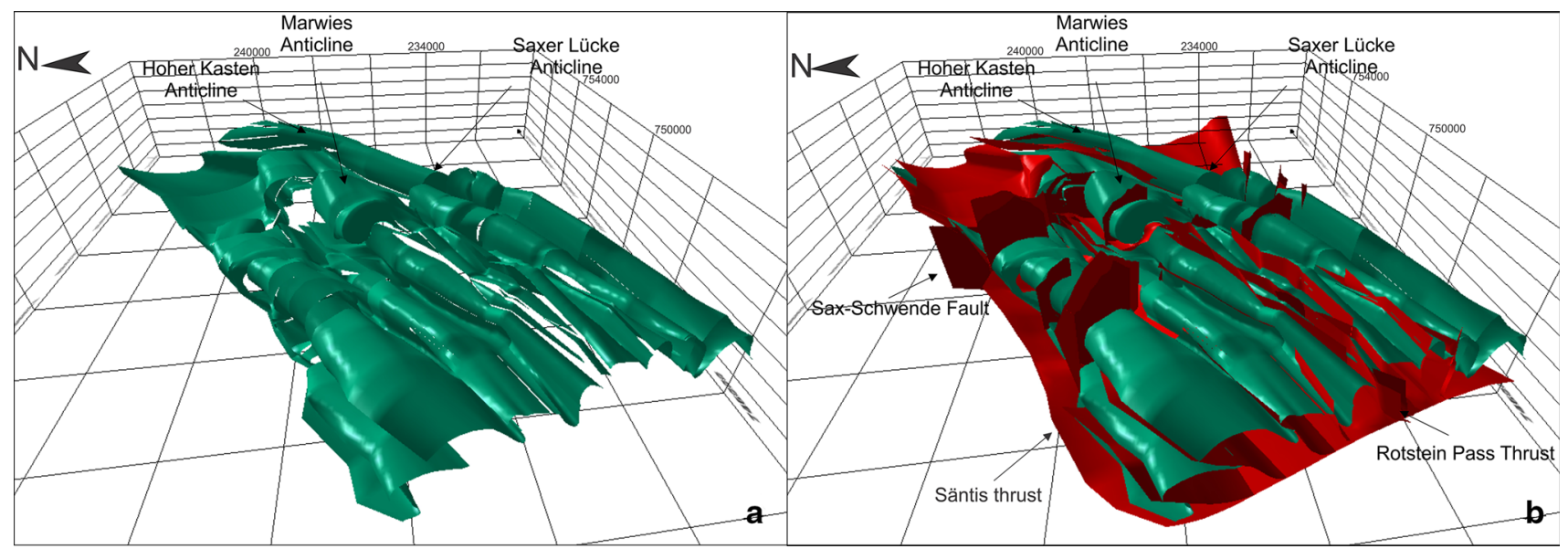

Fig. 7 Oblique view of the Schrattenkalk top surface, looking towards E, with (a) and without (b) faults. The model displays the complex structural architecture of the western block (in front) and the relatively simpler structure of the eastern block (at the back)

Fig. 8 Map showing the key structures and structural domains recognized in the model. The Sax-Schwende Fault divides the study area into a western block and an eastern block. The western block is further divided by the Rotstein Pass Thrust into a northern part characterized by thrusting (in blue) and a southern part with open folding (orange). The same color code is used in the eastern block, which is characterized by open and recumbent folding

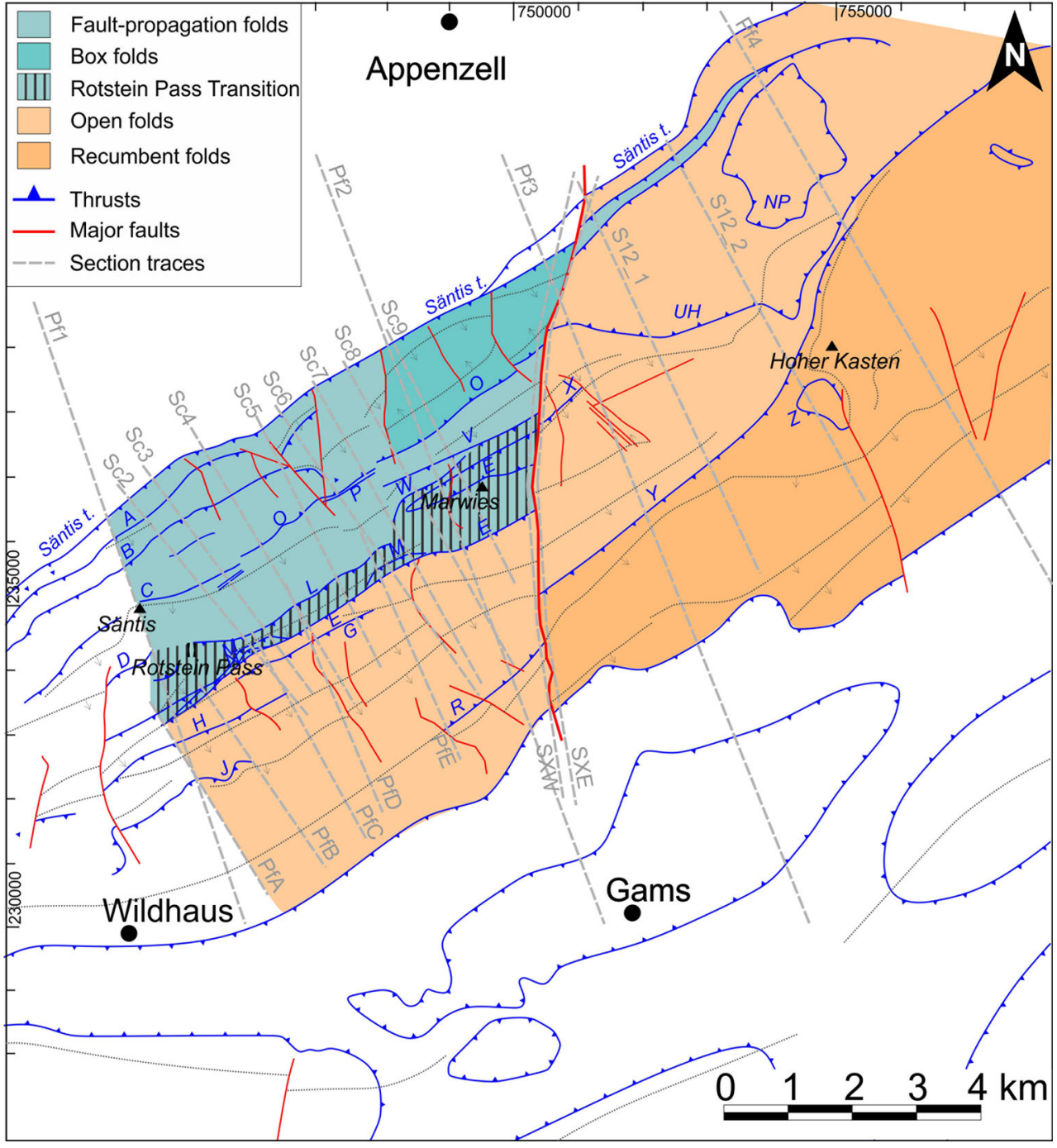


Fig. 9 a The Vitznau Marl and Öhrli Limestone top surfaces in a lateral view looking toward the East showing their relative position to the Sax-Schwende Fault and the Rotstein Pass Thrust. b Side view of the western block of the model looking towards the northeast showing the transition from pervasive thrusting in the North to open folding in the South. In the Rotstein Pass area, the coexistence of Vitznau Marl, Öhrli Limestone, and Öhrli Marl delineate a transition zone with intense imbricate thrusting immediately north and south of the Rotstein Pass Thrust

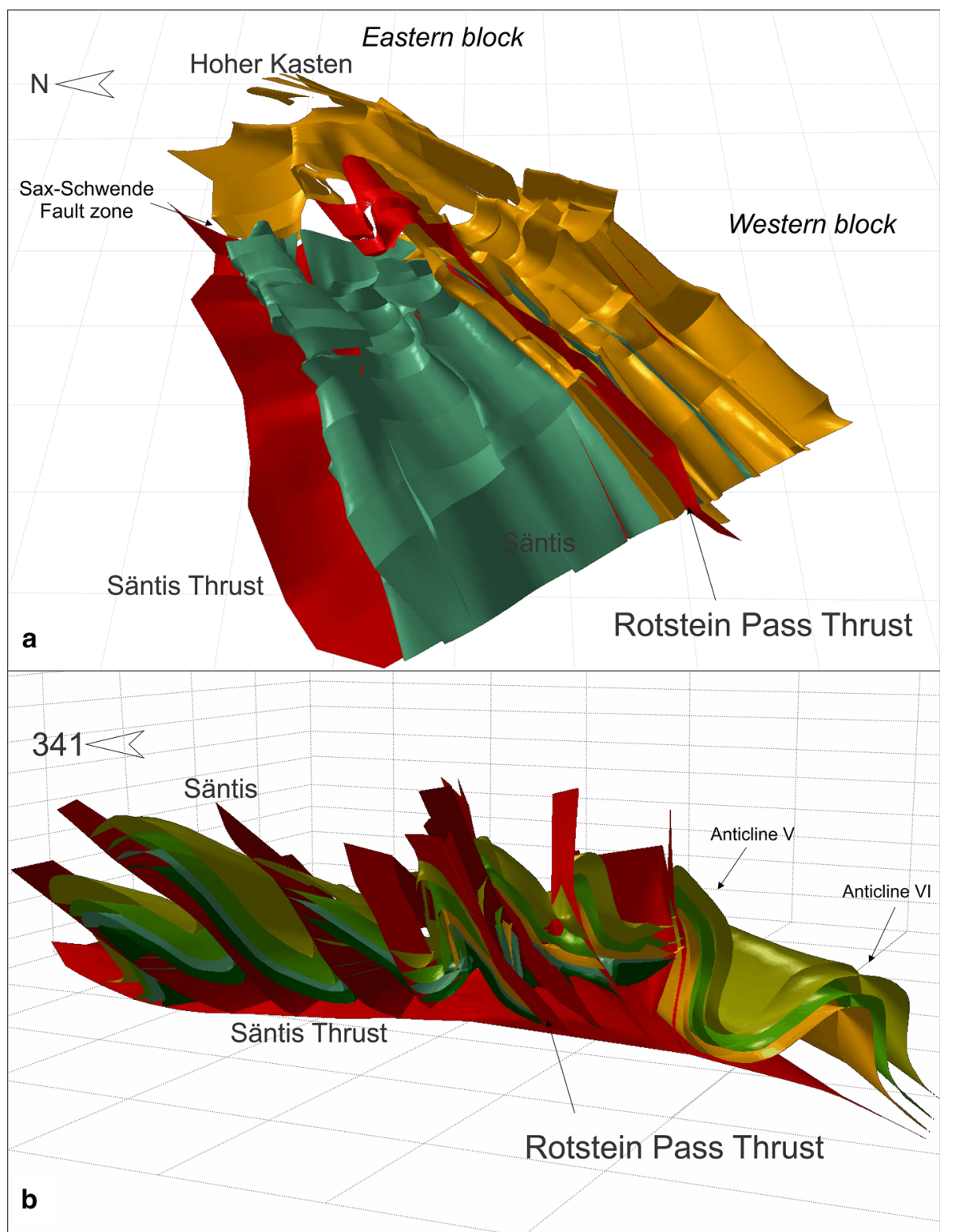

shortening for the eastern block. In the Vorarlberg area in Austria, a continuation of this west-east shortening gradient is observed from $30 \%$ just east of the Rhine Valley to $16 \%$ in the Iller Valley (Zerlauth et al. 2014). In our model, there is an additional shortening gradient inside the western block (Fig. 12), where the shortening increases from south to north: the cross-section set in the North from Schlatter (1941) reveals shortening values of $60 \%$ while the set in the South from Pfiffner (2011) exhibits an average shortening of $47 \%$.

These changes in shortening can be related to both changes in thickness of the formations and changes in the structural style. In the eastern block and in the South of the western block, where the Vitznau and Öhrli Marl are present and the Öhrli Limestone thins out (Fig. 8), the stratigraphic sequence is thicker and the structural style is dominated by open folding or detachment folding. There are only few thrust faults shortening the nappe in these parts, apart from thrust $\mathrm{Y}$ in the eastern block. The resulting shortening is relatively low (Fig. 12). Vice versa, where the sequence is thinner and there is only one marly interval acting as a detachment level (as in the North of the western block), the shortening is larger and accommodated by single trains of fault-propagation folds that can be followed for 


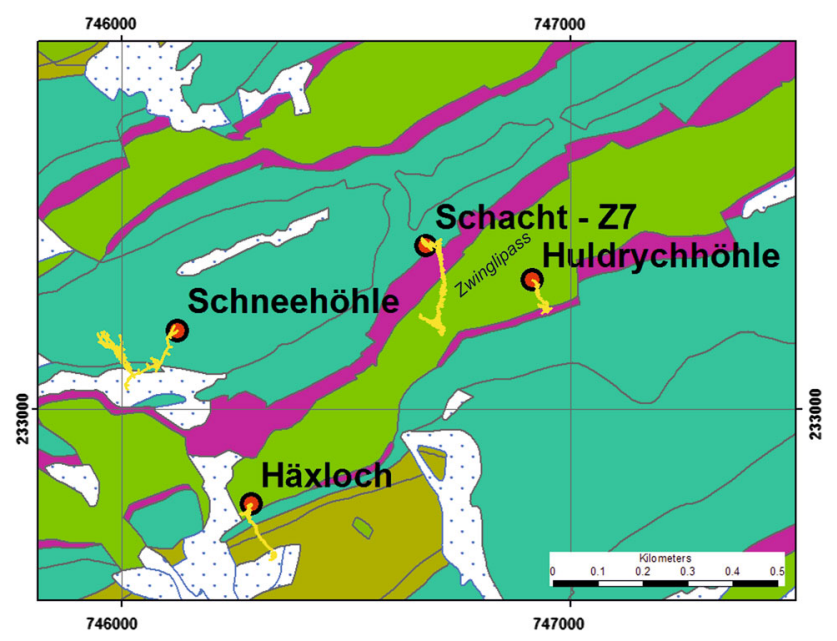

Fig. 10 Detail of the Zwingli Pass area with the location of the four caves and their extent in map view. Note that all of the caves cut across one or more geological boundaries

long distances along strike. Where the stratigraphy is complete and we have two distinct detachment levels, the sequence is dominated by complex imbricate thrusting, as in the Rotstein Pass area (Fig. 8).

\subsection{Nature of the Sax-Schwende Fault (and other palaeogeographic considerations)}

It is interesting to note that the Sax-Schwende Fault could be restored, with a translation movement toward south, to a position on the eastern flank of the Verrucano basin of the Glarus nappe. Inversion of this Permian basin uplifted the central part of the basin (Pfiffner 2009). The lateral N-S striking ramp along the eastern border of the Verrucano basin may have had an effect on the overlying Mesozoic strata and possibly initiated the Sax-Schwende Fault. This would explain that the internal structures of the Säntis nappe in the two blocks separated by this fault partly evolved independently, each with a different history and deformation style. Our structural model may be used in future studies to confirm the connection between the SaxSchwende Fault and the eastern flank of the Permian Verrucano basin.

The eastern block of our model comprises sediments that were deposited palaeogeographically deeper than in the western block, reflected by the distribution of the Vitznau Marl covering the entire eastern block. Upon restoration, the eastern block is shorter than the western block. We interpret the Sax-Schwende Fault zone as an inherited margin (a reactivated normal fault bounding the Permian through of the Verrucano deposits). This extensional normal fault has created space that accommodated the deposition of the marly facies and later acted as a lateral ramp for the Säntis Thrust. Similar structures and formation mechanisms can be found in similar fold-andthrust belts (e.g., the Loch Assynt Fault in the Moine Thrust Belt, north-western Scotland; Krabbendam and Leslie 2010).

Considering its position relative to the distribution of the marly intervals, the Rotstein Pass Thrust can also be interpreted as a palaeogeographic feature: an ancient shelf margin where the basin deepened, similar to the SaxSchwende Fault, but with an orientation at right angles. This would explain the distribution of the Vitznau Marls concentrated only in the South of the western block (Fig. 9).

\section{Conclusions}

The presented 3D structural model of the Säntis area, constructed using interpreted cross-sections, allows the following conclusions to be drawn.

1. The Sax-Schwende Fault cuts through the basal Säntis Thrust and divides the Säntis nappe into two distinct blocks, a higher western block and a lowered eastern block, each with a different deformation history and structural style.

2. The Rotstein Pass Thrust further divides the western block into two sub-blocks with different stratigraphy and different structural style. Imbricate thrusting prevails north of the Rotstein Pass; open folding dominates in the southern sub-area. Changes in the structural style can be related to lateral variation of the stratigraphic sequence, where either single (north) or multiple (south) detachment levels occur. This structural organization may reflect an inherited palaeotopography, like palaeomargins of the European shelf, subsequently reactivated as frontal and lateral ramps. The Rotstein Pass could have marked a deepening of the shelf, south of which the Vitznau Marls were deposited.

3. The genesis of the Sax-Schwende Fault could be related to the inversion of the Verrucano basin in the Glarus area. During the Mesozoic, the fault could have acted as a palaeomargin influencing the stratigraphy, and delimiting a deeper realm in the East. Finally, the Sax-Schwende Fault may have been active from the early phases of pre-folding, enabling an almost independent deformation east and west of the fault, resulting in different folding styles.

Interesting future studies include a 3D restoration of the model to further quantify lateral shortening gradients and a restoration at a bigger scale, sliding the model onto the Glarus Thrust to confirm the relationship 
Fig. 11 3D oblique views of caves and their intersection with modeled lithological interfaces. The transparent grey surface is the DEM. The caves are represented as a cloud of points, each point representing a reference point in the cave. The entrance opening of the cave is indicated with a red point. a Oblique view of the Häxloch cave, starting in the

Schrattenkalk, developing mostly in the Helvetischer Kieselkalk, and ending in the Betlis Formation; b oblique view of the Huldrychhöhle, opening in the Seewen Formation, crossing the Garschella Formation, and ending in the Schrattenkalk; c Oblique view of the SchachtZ7, following mostly the Schrattenkalk, crossing twice the Garschella and Seewen Formations; d Oblique view of the Schneehöhle, mostly developing in the Schrattenkalk, a branch crossing the boundary with the Helvetischer Kieselkalk. Because a-d are views from within the model, they are very challenging visualizations. For a better feel of the 3D nature of the cave data it is therefore recommended to download the full model (including the cave data) from Online Resource 1 in the online version of the journal and "fly" through the model, interactively
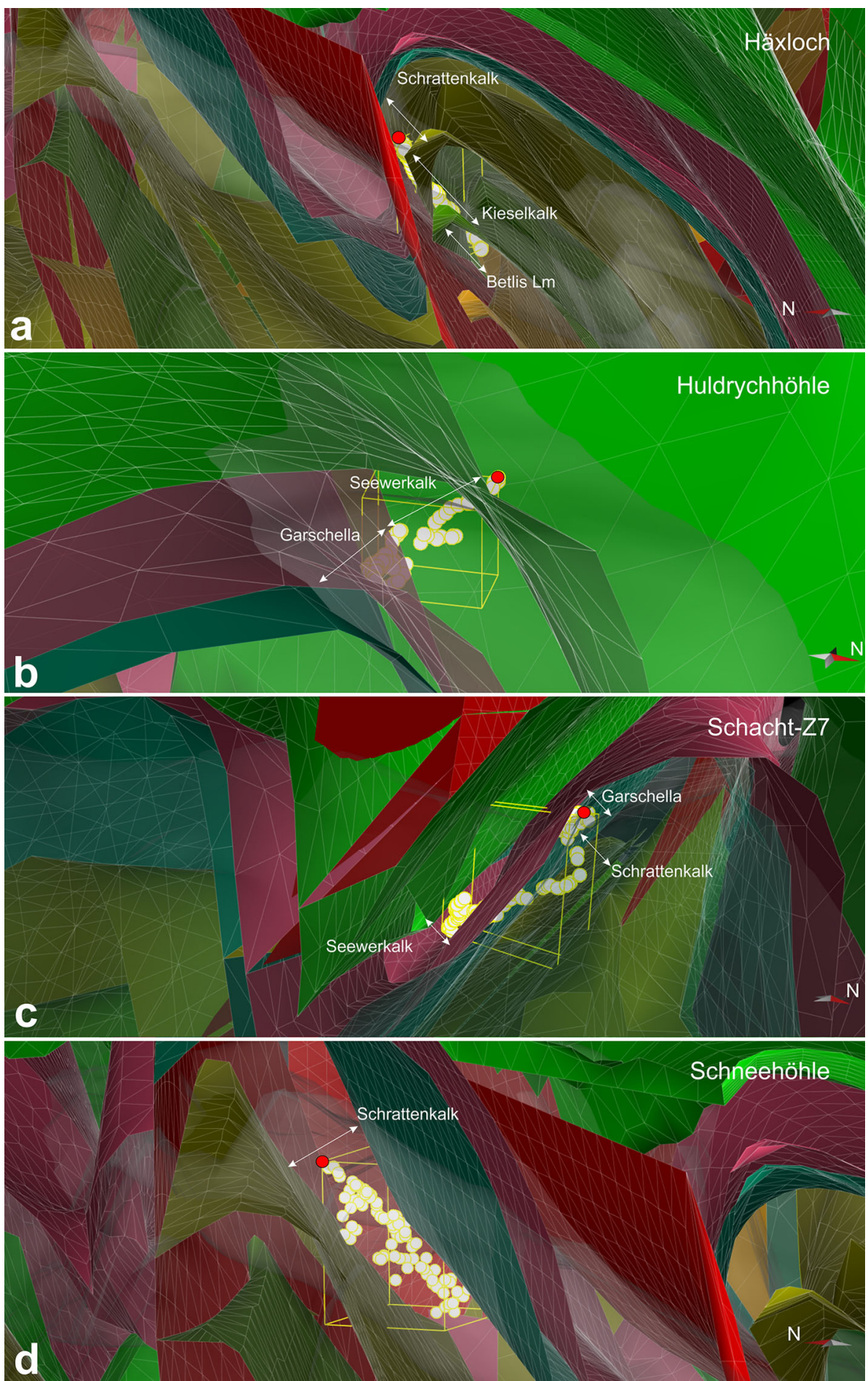

between the Sax-Schwende Fault and the Verrucano basin flank.

Our structural model could also be integrated and compared with Zerlauth et al. (2014) in order to see a correlation with the structures east of the Rhine Valley. Finally, the model could be expanded to the West to include the area of the western Säntis and the Drusberg nappe. 
Fig. 12 Bulk shortening calculated for each crosssection, based on the Schrattenkalk cross-section length (for the data, see Table 2). The highest shortening values occur in the western block, particularly in the northern part. This is consistent with the nature of the structures in the different structural domains. The eastern block has lower shortening values. The slightly higher shortening value of crosssection S12-2, is due to the presence of a tectonic window in the Hoher Kasten area



Acknowledgments We thank Pemex-Petróleos Mexicanos for the financial support and Midland Valley Ltd for providing the academic license of Move and software support. The Speleological Group of Eastern Switzerland (OGH), and in particular Richard Graf, is gratefully acknowledged for providing the cave data and for extensive discussions and enthusiasm about this project. We also thank the reviewers for valuable suggestions and improvements to the manuscript.

\section{References}

Allan, U. S. (1989). Model for hydrocarbon migration and entrapment within faulted structures. American Association of Petroleum Geologists Bulletin, 73, 803-811.

Bolli, H. (1944). Zur Stratigraphie der Oberen Kreide in den höheren helvetischen Decken. Eclogae Geologicae Helvetiae, 37, 216-330.

Bollinger, D. (1988). Die Entwicklung des distalen osthelvetischen Schelfs im Barremian und Früh-Aptian: Drusberg-, Mittagsspitzund Schrattenkalk-Fm. im Vorarlberg und Allgäu. Dissertation, University of Zürich, Switzerland.
Burger, H., \& Strasser, A. (1981). Lithostratigraphische Einheiten der untersten Helvetischen Kreide in der Zentral- und Ostschweiz. Eclogae Geologicae Helvetiae, 74, 529-560.

Cristallini, E. O., \& Allmendinger, R. W. (2001). Pseudo 3-D modelling of Trishear Fault Propagation Folding. Journal of Structural Geology, 23, 1889-1899.

Eugster, H., Forrer, M., Frohlicher, H., Kempf, T., Schlatter, L., Blaser, R., Funk, H., Langenegger, H., Spoerri, M., Habicht, K. (1982). Säntis (map sheet 1115), Geological Atlas of Switzerland 1:25.000, N. 78. Federal Office of Topography (Swisstopo).

Fernández, O. (2005). Obtaining a best fitting plane through $3 \mathrm{~d}$ georeferenced data. Journal of Structural Geology, 27, $855-858$.

Fernández, O., Jones, S., Griffiths, P., Armstrong, N., Johnson, G., Ravagila, A., et al. (2009). Automated tools within workows for $3 \mathrm{~d}$ structural construction from surface and subsurface data. Geoinformatica, 13, 291-304.

Föllmi, K. B., \& Ouwehand, P. J. (1987). Garschella-Formation und Götzis-Schichten (Aptian-Coniacian): Neue stratigraphische Daten aus dem Helvetikum der Ostschweiz und des Vorarlberges. Eclogae Geologicae Helvetiae, 80, 141-191.

Funk, H. (1969). Typusprofile der helvetischen Kieselkalk-Formation und der Altmann-Schichten. Eclogae Geologicae Helvetiae, 62, 191-203. 
Funk, H., Habicht, K.J., Hantke, R., Pfiffner, O. (2000). Geologischer Atlas der Schweiz 1:25.000-Blatt Säntis (inkl. Erläuterungen). Bundesamt für Wasser und Geologie, Bern.

Grasmück-Pfluger, M. (1962). Mikrofazielle Beobachtungen an den Öhrlischichten (Berriasian) der Typuslokalität. Eclogae Geologicae Helvetiae, 55, 417-442.

Groshong, R., Pfiffner, O., \& Pringle, L. (1984). Strain partitioning in the helvetic thrust belt of Eastern Switzerland from the leading edge to the internal zone. Journal of Structural Geology, 6, 5-18.

Heim, A. (1905). Das Säntisgebirge. Verhandlungen der Schweizerischen Naturforschenden Gesellschaft, 88.

Kempf, T. (1966). Geologie des westlichen Säntisgebirges. Beiträge zur geologischen Karte der Schweiz, 128. Federal Office of Topography (Swisstopo).

Kempf, O., \& Pfiffner, O. (2004). Early Tertiary evolution of the North Alpine Foreland Basin of the Swiss Alps and adjoining areas. Basin Research, 16, 549-567.

Krabbendam, M., Leslie, A.G. (2010). Lateral variations and linkages in thrust geometry: The Traligill Transverse Zone, Assynt Culmination, Moine Thrust Belt, NW Scotland. Geological Society, London, Special Publications, 335, 335-357.

Oberhänsli-Langenegger, H., (1978). Mikropaläontologische und sedimentologische Untersuchungen in der Amdener Formation (Oberkreide, Helvetische Decken der Schweizer Alpen). Beiträge zur geologischen Karte der Schweiz. Neue Folge 150, 1-83.

Pfiffner, O. (1981). Fold-and-thrust tectonics in the Helvetic Nappes (E Switzerland). In Thrust and Nappe Tectonics, Geological Society, London, Special Publications, 9, 319-327. doi:10.1144/ GSL.SP.1981.009.01.28.

Pfiffner, O. (1985). Displacements along thrusts folds. Eclogae Geologicae Helvetiae, 78, 313-333.
Pfiffner, O. (1993). The structure of the Helvetic Nappes and its relation to the mechanical stratigraphy. Journal of Structural Geology, 15, 511-521.

Pfiffner, O. (2009). Geologie der Alpen. Bern: Haupt. ISBN 978-38252-8416-9.

Pfiffner, O. (2011). Structural map of the Helvetic Zone of the Swiss Alps including Vorarlberg (Austria) and Haute Savoie (France). Geological Special Map 1:100.000, Explanatory notes. Federal Office of Topography (Swisstopo).

Sala, P., Frehner, M., Tisato, N., \& Pfiffner, O. (2013). Building a 3D near-surface geological and petrophysical model based on borehole data: a case-study from Chémery, Paris Basin, France. American Association of Petroleum Geologists Bulletin, 97, 1303-1324.

Schlatter, L. (1941). Neue Geologische Untersuchungen in Mittleren Säntisgebirge. Ph.D. Dissertation, Univeristy of Basel, Switzerland, $\mathrm{p} 70$.

Tanner, D., Behrmann, J., \& Dresmann, H. (2003). Three-dimensional retro-deformation of the Lechtal nappe, Northern Calcareous Alps. Journal of Structural Geology, 25, 737-748.

Wilkerson, M. S., Medwedeff, D. A., \& Marshak, S. (1991). Geometrical modelling of fault-related folds: a pseudo threedimensional approach. Journal of Structural Geology, 13, 801-812.

Zanchi, A., Salvi, F., Zanchetta, S., Sterlacchini, S., \& Guerra, G. (2009). 3D reconstruction of complex geological bodies: examples from the Alps. Computers and Geosciences, 35, 49-69.

Zerlauth, M., Ortner, H., Pomella, H., Pfiffner, O. \& Flügenschuh, B. (2014). Inherited tectonic structures controlling the deformation style: an example from the Helvetic nappes of the eastern Alps. Submitted to Swiss Journal of Geoscience, 107(2-3). 